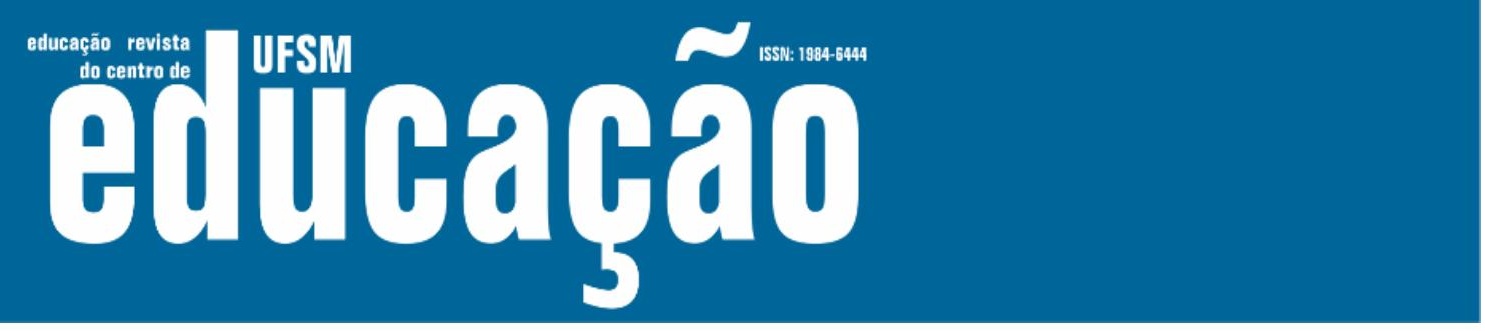

ISSN: 1984-6444 | http://dx.doi.org/10.5902/1984644444577

\title{
Experiência, Juventude e o estar-junto em processos de aprendizagem em dança: por uma Pedagogia Performativa
}

Experience, youth and being together in dance learning processes: for performative pedagogy

Roberto Rodrigues

Docente do Instituto Federal de Goiás, Aparecida de Goiânia, Goiás, Brasil. roberto.rodrigues@ifg.edu.br - orcid.org/0000-0002-9862-561X

Paulo Petronilio Correia

Professor Adjunto da Universidade de Brasília. Brasília, Distrito Federal, Brasil. ppetronilio@uol.com.br - orcid.org/0000-0001-7704-064X

Recebido em 26 de maio de 2020

Aprovado em 15 de junho de 2021

Publicado em 30 de dezembro de 2021

\section{RESUMO}

Este trabalho parte de reflexões sobre experiências docentes no curso de Licenciatura em Dança do Instituto Federal de Goiás/ Campus Aparecida de Goiânia, no contexto específico das disciplinas Ateliê de criação em dança I e II, onde propõem-se o estudo e vivências de diferentes acervos de dança e seus processos de ensino-aprendizagem a partir da criação artística como eixo norteador das relações entre os sujeitos e o estar-junto como paradigma ético e estético. Metodologicamente trabalhamos com a revisão de literatura que tenta dar conta das questões que envolvem a dança e a Pedagogia performativa levando em consideração as experiências nos Ateliês de criação. A presente reflexão aponta para a possibilidade da construção de novos olhares em torno dos saberes formativos na trajetória a partir da perspectiva da Experiência e da Pedagogia Performativa pensadas em contextos de Juventude. Tais processos são experimentados em uma Instituição Pública de Ensino que se compromete com a problematização e a recriação de práticas específicas e modos de ser no seio dos diversos grupos sociais. O contato sistemático e criativo com a diversidade cultural presente nesses acervos de dança a partir da utilização de metodologias coletivas e participativas sob a perspectiva da Pedagogia Performativa tem contribuído para um processo sistemático e multidimensional orientado à formação do sujeito de direito e a promoção de uma socialidade ativa e participante.

Palavras-chave: Dança; Experiência; Pedagogia Performativa.

\section{ABSTRACT}




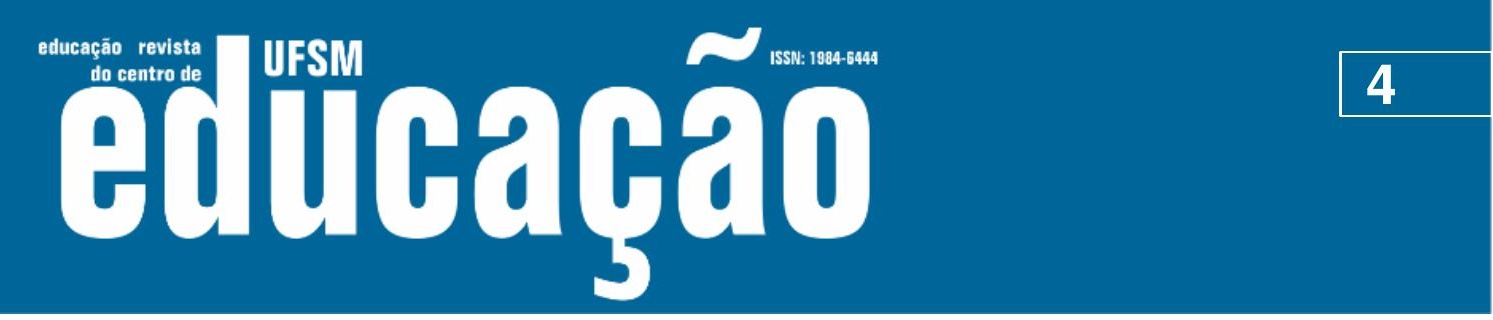

ISSN: 1984-6444 | http://dx.doi.org/10.5902/1984644444577

experiência como aquela que nos passa e nos atravessa nesses espaços compostos pela juventude tal como propôs Freitas (2005), enraizadas nos cruzamentos da pedagogia e da performance de Pineau (2010).

Para melhor facilitar a leitura esse artigo está dividido em subtópicos interrelacionados de forma objetiva e didática. No primeiro, trazemos a perspectiva da experiência como lugar de criação, onde apresentamos os ateliês como lugar para pesquisar, questionar e investigar. "Experiência e juventude: criar para ser". Aqui enfatizamos que o termo Juventude é compreendido de maneira ampliada como fenômeno histórico, político e cultural. Em "Estar junto como potência na educação pública", problematizamos pelo viés maffesoliano a noção de estar-junto conectado a uma ética e a uma estética da vida cotidiana. Por fim, no subtópico "Por uma pedagogia performativa: ensinar é tecer", destacamos a ideia da performance como algo que fortalece a pedagogia. Daí, a Pedagogia Performativa se fortalece na experiência vivida e tecida junto.

É importante ressaltar que durante o texto alguns termos aparecerão em itálico por se tratar de conceitos-chave que atravessam este estudo e que foram cunhados por autores com quem dialogamos ao longo da escrita e, que, portanto, achamos ser necessário serem destacados. Além deles, o nome Ateliê de criação em dança e em alguns momentos somente Ateliê, também aparecem em destaque ao longo do texto.

\section{A experiência como lugar de criação}

Parafraseando Klauss Vianna (2005), costumo dizer aos meus alunos: eu não danço, eu sou a dança! E nenhum lugar é melhor para se pensar a criação na dança como a experiência. Não se trata de uma experiência que se passa, mas aquela originária, experiência fundamental, "ontológica" que nos passa, que nos movimenta, nos afeta e nos atravessa. Nos Ateliês de criação em dança I e II o que se tem proposto é que os sujeitos da experiência pesquisem os efeitos, os vestígios que a sua cultura deixa através das marcas, dos rastros que se apresentam para nós a partir dos corpos, movimentos que se apresentam, se ex-põe para nós pelas/nas danças. É a partir daí que podemos criar novos lugares de inserção poética na/pela dança 


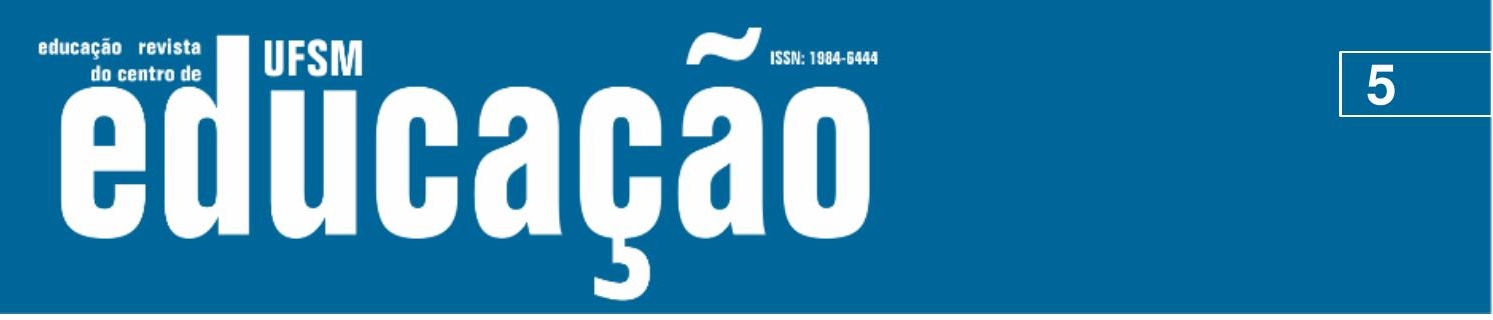

ISSN: 1984-6444 | http://dx.doi.org/10.5902/1984644444577

trazendo à tona traços, qualidades, acentuações nos corpos desses sujeitos da experiência. Portanto, não se trata apenas de reproduzir gestos, movimentos e comportamentos identificados em suas culturas. Os Ateliês de criação em dança caminham no sentido de provocá-los a trazer tais experiências para desconstruí-las e, certamente, reconstruí-las de outros modos.

Os Ateliês se constituem, então, como lugar para pesquisar, investigar, esburacar, questionar e abrir espaços para a criação, para o novo, o inusitado. A criação aqui é vista como potência, como possibilidade de invenção. Invenção essa que não se dá a partir da estaca zero é, pelo contrário, partir do que já está estabelecido e provocar questões, no nosso caso, questões do próprio corpo e do movimento para ampliar as experiências em dança.

(...) seja ela qual for, o que se pretende é proporcionar aos estudantes a capacidade argumentativa conquistada com as vivências, com 0 experimentar. Não é o domínio intelectual, externo, conteudista a predominar. $\mathrm{E}$ sim as múltiplas experiências, a diversidade, a intensidade, a contradição. E com a dança, na multiplicidade de corpos, nas sensações, no mover-se. E o foco não é algo externo, fora do contexto, daquele real vivido com aquele grupo de estudantes e sim, neles, na conquista de poéticas do coletivo e das poéticas pessoais. (RIBEIRO, 2018, p.8)

As experiências provocadas nos Ateliês se direcionam, então, à construção de argumentos no corpo que podem ser fabricados através das vivências, experimentações e contextualizações das danças no mundo. O foco é a troca de experiências entre os sujeitos, as danças e os espaços onde elas acontecem para que os mesmos conquistem autonomia para experimentar, criar e transformar os saberes e suas próprias realidades através dele.

Aqui destacamos a investida nas experiências adquiridas ao longo das trajetórias docente e discente a partir de processos de conquistas, de construção de saberes que se dão nas dimensões individual e coletiva através do contato, do compartilhamento, da troca, da criação e da invenção. Requer, portanto, que tanto professores quanto alunos sejam ex-postos às marcas, aos rastros, aos fragmentos e às diferentes nuances de tais experiências.

Metodologicamente, as experimentações nos Ateliês I e II, partem de quatro princípios que norteiam todo o processo de ensino-aprendizagem-criação nessas 


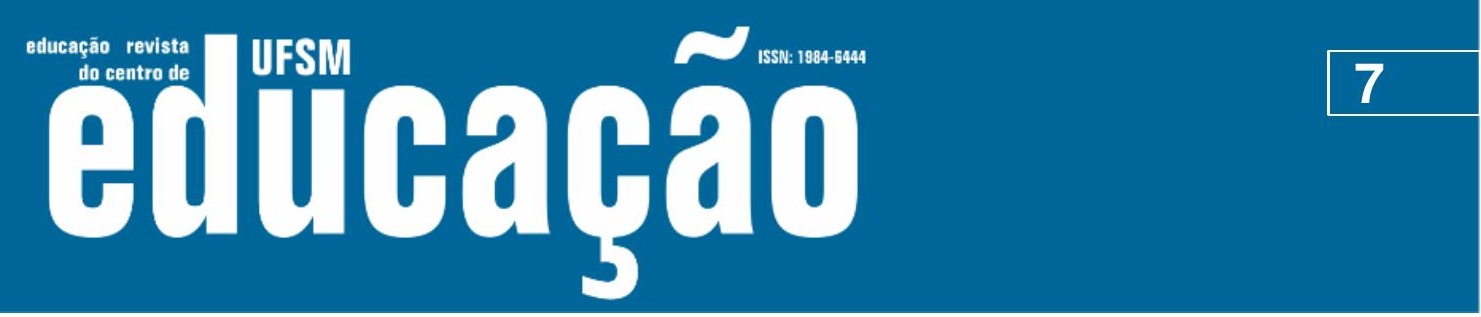

ISSN: 1984-6444 | http://dx.doi.org/10.5902/1984644444577

de Isabel Marques e sua proposta metodológica da Dança no Contexto3. No modo como articulamos os estudos de Isabel, propomos algumas referências de observação e pesquisa a partir da exploração de ações, qualidades do movimento e as relações que o corpo estabelece com os espaços onde a dança acontece.

Cabe aqui ressaltar que as pesquisas de movimento, da forma como compreendemos e propomos nos Ateliês I e II, se aproximam do entendimento de que explorar os acervos específicos não se limita à aprendizagem de passos codificados presentes nessas danças. Trata-se, antes, da identificação e experimentação de modos de saber e fazer como possibilidades oferecidas por corpos no tempo e no espaço delineando motivações, intenções, razões e significações (MARQUES, 2010).

Imagem 1 - experimentações nos Ateliês I e II (2016)
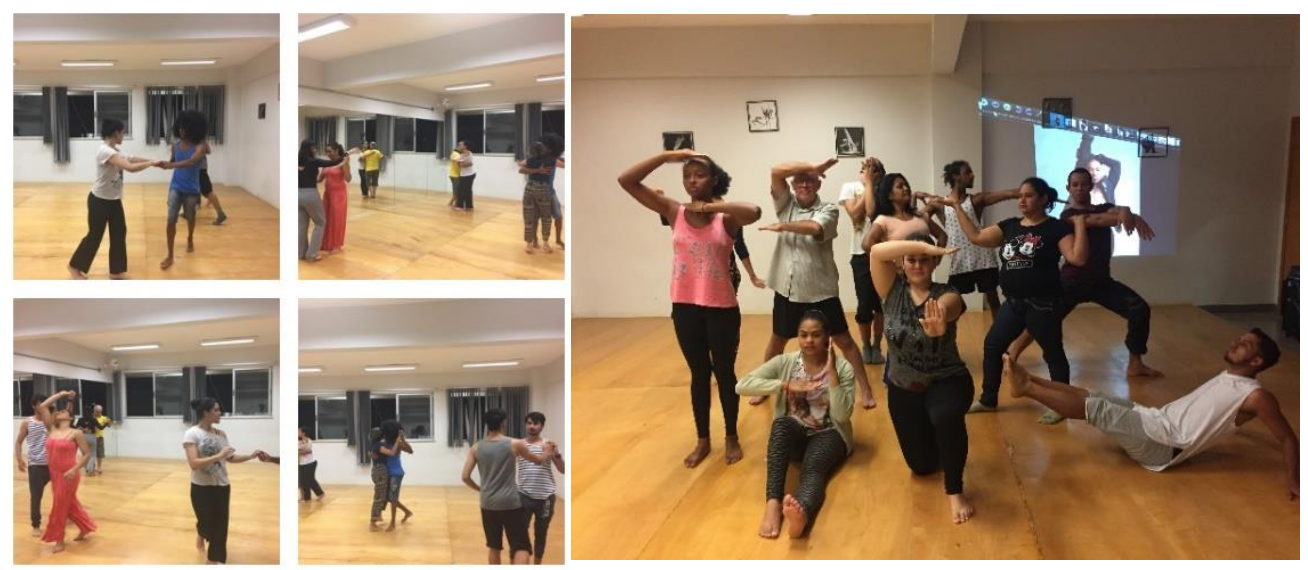

Fonte: Acervo pessoal ${ }^{4}$

Como nos aponta Molina (2018) tal proposição pressupõe um estado de abertura nessa relação com o outro e com o mundo; um lugar de atravessamentos, que é possibilitado pelo estado de exposição, e que é delineado por um espaço indeterminado e perigoso. Estas características de atravessamento, imprevisibilidade e exposição se configuram, conforme destaca Larrosa, também como pressupostos de formação e transformação. 


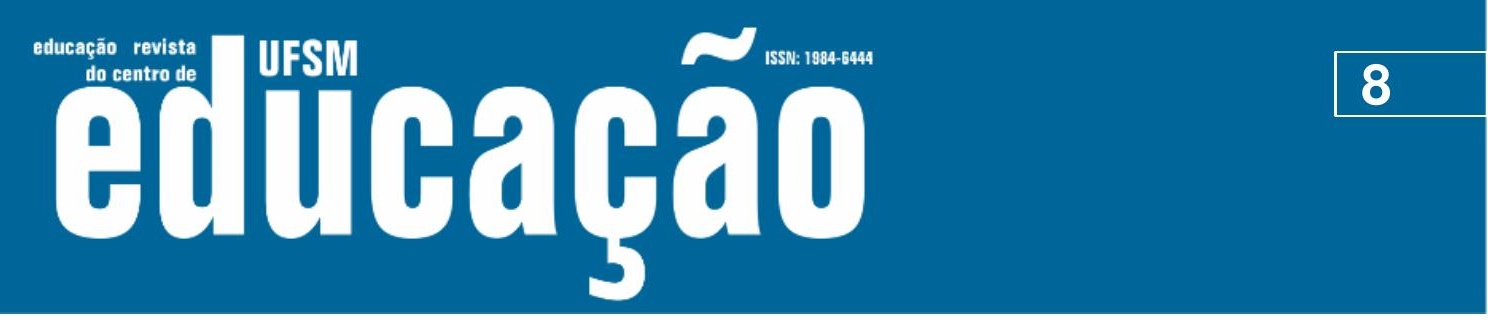

ISSN: 1984-6444 | http://dx.doi.org/10.5902/1984644444577

O sujeito da experiência tem algo desse ser fascinante que se expõe atravessando um espaço indeterminado e perigoso, pondo-se nele à prova $\mathrm{e}$ buscando nele sua oportunidade, sua ocasião. A palavra experiência tem o ex de exterior, de estrangeiro, de exílio, de estranho e também o ex de existência. (...) é experiência aquilo que "nos passa", ou que nos toca, ou que nos acontece, e ao nos passar nos forma e nos transforma. Somente o sujeito da experiência está, portanto, aberto à sua própria transformação. (LARROSA, 2015, pp.25-26)

As experiências proporcionadas buscam, então, atravessar os sujeitos, oportunizando o contato com o novo, o inesperado, o inusitado. São descobertas que acontecem no corpo e transformam suas próprias experiências, enriquecendo-as, alimentando e ampliando seus olhares, seus modos de lidar com tais conhecimentos e que, posteriormente, também serão ex-postos por esses sujeitos em suas práticas profissionais, transformadas em trabalho.

O terceiro princípio - a experiência cênica como construção de poéticas individuais e coletivas - se direciona às oportunidades de experimentação cênica a partir de criações individuais e coletivas propostas para serem compartilhadas de diferentes modos, de acordo com as especificidades de cada turma e em acordo com as particularidades de cada semestre em que os Ateliês são vivenciados. Algumas das estratégias escolhidas para os compartilhamentos são: intervenções artísticas, coreografias, performances, dentre outras.

Essas experiências permitem que os sujeitos se coloquem em ex-posição, na perspectiva já apontada por Larrosa (2015). Um modo de se arriscar na experiência cênica que possibilita deixar-se atravessar pelas relações que o corpo estabelece com o espaço, com os outros e todos os desafios disparados pelas ocasiões em que se aventuram. 


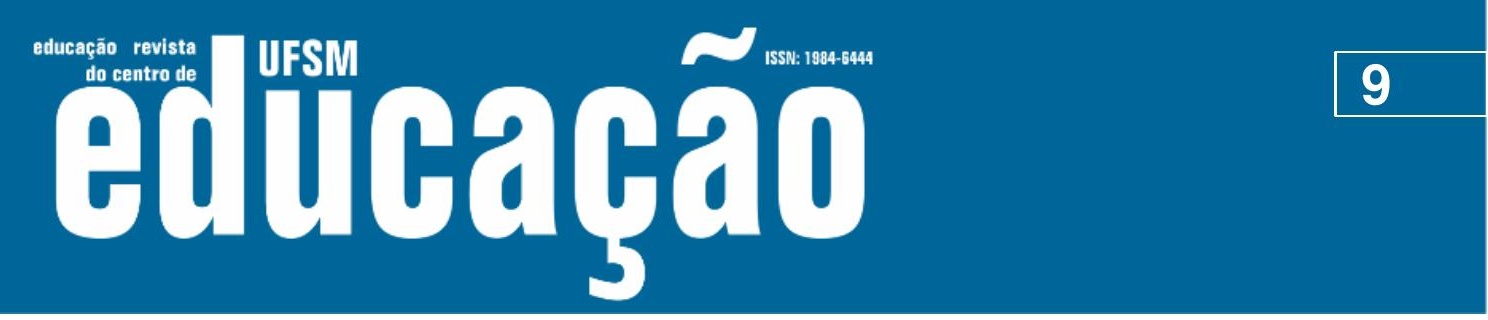

ISSN: 1984-6444 | http://dx.doi.org/10.5902/1984644444577

Imagem 2 - Salões - intervenção cênica no evento Dança à Mostra $2016^{5}$.

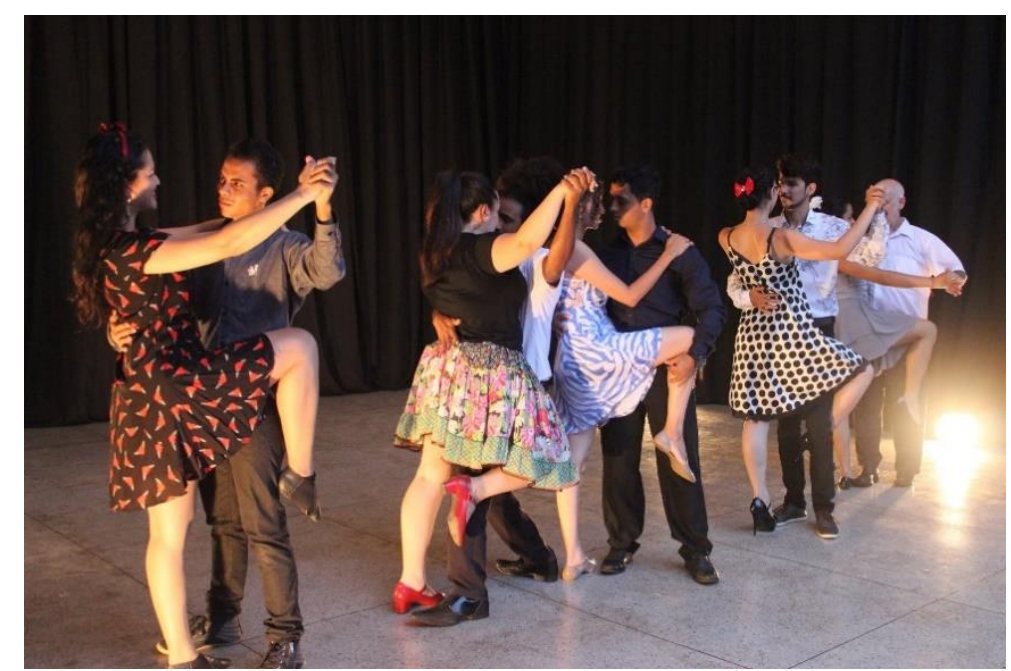

Fonte: Acervo pessoal.

A partir das experiências cênicas é possível refletir sobre diferentes estratégias e procedimentos criativos em dança, problematizando as práticas de criação de movimentos e de composição coreográfica. Aqui, nos aproximamos das ideias de Luciana Paludo (2015) acerca da coreografia como um dos procedimentos de ensino e, também, como recurso pedagógico. Nas palavras da própria autora, "é um conceito operatório, compreendida também como um recurso pedagógico" (PALUDO, 2015, p.16). Neste sentido, o conceito de coreografia é ampliado pelas noções contemporâneas em que para a criação coreográfica existem inúmeras possibilidades de investigação e pesquisa de movimentos. Estas nem sempre estão atreladas somente a repertórios pré-estabelecidos, mas à capacidade de criar corporalmente diferentes caminhos e possibilidades de expressão pelo/do movimento.

Ao longo dessas experiências algumas questões sempre surgem: O que é de fato estudar dança? O que é pesquisar? O que é experimentar? Como se constituem estes saberes? Quando experimentamos, buscamos novas possibilidades para a construção do conhecimento. Desviamo-nos das individualidades, no sentido estrito da palavra e atingimos realidades mais amplas, que saltam, extrapolam os pequenos espaços e chegam às concretudes mais extensas. 


\section{N-Tism

ISSN: 1984-6444 | http://dx.doi.org/10.5902/1984644444577

Contextualizar e investigar problemas sejam eles de ordem conceitual, teórica, ou da própria prática, das próprias corporeidades que estão presentes nestes acervos, nos permite entrar em contato com as diferentes realidades das danças. Todo acervo está inserido socialmente e é contaminado, transformado, atravessado por essa realidade.

O quarto princípio - contato com artistas externos convidados semestralmente para partilhar pesquisas corporais em acervos específicos escolhidos em acordo entre professor e alunos/as/es - se constitui pelo desejo em trocar com artistas da cena e que trabalham especificamente com alguns acervos estudados nos Ateliês I e II. Esse contato acontece pela partilha de experiências e pela democratização do conhecimento em dança. Atualmente, o Ateliê I conta com a participação de jovens pesquisadores e artistas da dança que atuam profissionalmente em diferentes espaços da cidade de Goiânia e que, a cada oferta desta disciplina, retornam à Instituição para compartilhar algumas vivências.

Ao longo dessas partilhas buscamos dialogar com esses artistas sobre aspectos estéticos e metodológicos em torno dos seus processos pedagógicos em dança, como forma de potencializar essas vivências e de algum modo refletir criticamente em torno delas. Como são ensinadas? Que tipos de pedagogias imperam? Onde são ensinadas e aprendidas? E como ocorre esse aprendizado? Existe algum tipo de exigência técnica, motora e/ou sinestésica para se dançar? 0 que leva as pessoas a procurarem essas danças? Tais questões têm surgido ao longo das experiências dos Ateliês e se direcionam aos fatores que estão intimamente ligados à constituição dos saberes em dança e das experiências que se apresentam, se ex-põem, formam e transformam os sujeitos. 


\section{$\sim 7$

ISSN: 1984-6444 | http://dx.doi.org/10.5902/1984644444577

O desafio, então, não é somente dominar um determinado vocabulário, constituir as ferramentas de uma linguagem artística, mas sim, do desenvolvimento das potencialidades sinestésicas de produzir, criar, comunicar, sentir e inter(agir) com distintos vocabulários, atentos às diferentes línguas que compõem esses diálogos, com um aumento progressivo na intervenção e em suas próprias ações.

Nesse terreno da construção de saberes o tempo é outro, diferente do tempo rápido, acelerado, agitado do mundo da ciência, do trabalho. Esses saberes são até transformados em trabalho, mas quando tratamos o próprio trabalho em sua natureza de criação, de construção humana. Assim, o saber da experiência é "o que se adquire no modo como alguém vai respondendo ao que vai lhe acontecendo ao longo da vida e no modo como vamos dando sentido ao acontecer que nos acontece" (LARROSA, 2015 p.32). Nesse sentido os saberes vão se constituindo na dilatação das relações de Juventude. No aumento da capacidade de dialogar, intervir e performar através de seus corpos, criando modos de vida artísticos.

Esses territórios incitam, assim, a construção de saberes que se adquirem na experiência, no desenrolar dos acontecimentos cotidianos da prática docentediscente. Tais saberes são da ordem das singularidades, da construção de sentidos e não da construção de verdades sobre a ordem das coisas, do conhecimento. Os saberes da experiência estão conectados efetivamente com os acontecimentos e não, somente, com os conteúdos, os conhecimentos em si. Isso tudo porque tratamos aqui de processos de construção de saberes em Arte, em Dança. E, assim admitimos que esse percurso

(...) pode ser considerado como percurso criador, feito de formas de caráter precário, pautado em hipóteses, fruto de um longo percurso de dúvidas, ajustes, certezas, acertos, aproximações, um movimento feito de sensações, ações, pensamentos, que sofre intervenções do consciente e do inconsciente, do que é objetivo e do subjetivo onde o professor e o aluno são autores, respeitadas as devidas particularidades. (PORTELA et al. 2016, p.235)

O percurso trilhado é o da descoberta, fruto de muitas pesquisas, investidas, criações e invenções. $O$ acoplamento de experiências entre docentes e discentes se dá como em um processo de mixagem, de junção, sobreposição, fusão, onde 


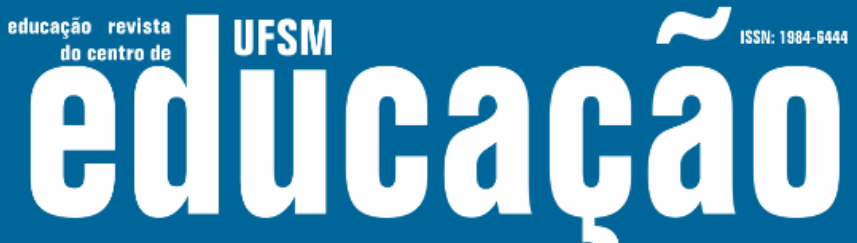

ISSN: 1984-6444 | http://dx.doi.org/10.5902/1984644444577

diferentes camadas vão se unindo para construírem os saberes em dança. Partindo sempre daquilo que já existe, o já conhecido, o percebido, mas, abrindo-se, também, ao desconhecido, o silenciado, o não percebido. Cada experiência, em cada Ateliê, ao longo dessa trajetória docente-discente vai sempre se reconstruindo e apontando novas pistas do que está por vir. Por isso os Ateliês têm se tornando um lugar de muitos atravessamentos, descobertas e transformação. Experiência e Juventude. Criação de diferentes modos de subjetivação.

Trazer as experiências de vida dos sujeitos e os saberes aí constituídos relacionando-os aos saberes da experiência dos diferentes acervos já constituídos historicamente, tem sido um bom exercício dialógico para disparar novas possibilidades artísticas e criativas para a inserção e trânsito desses sujeitos nos diferentes lugares sociais que ocupam, seja o contexto acadêmico, os lugares onde apresentam seus trabalhos artísticos ou até mesmo retornando aos seus próprios cotidianos de outra forma, seduzidos e transformados pelas poéticas que surgem de suas próprias experiências, dos seus movimentos e referências estéticas que são constantemente ressignificados neste lugar de pesquisa chamado Ateliê de criação em dança. Experimentar e contextualizar as práticas em um paradigma ético, estético e político torna-se fundamental, pois a experiência se constitui, também, como um lugar de relações e potências da coletividade, da construção de um estar-junto, o que colocaremos em miúdos no tópico a seguir.

\section{O estar-junto como potência na Educação Pública}

É impossível pensar esse complexo agenciamento que chamamos de educação sem pensarmos as relações entre sujeitos, a ética e a estética do estarjunto. Ao sermos impulsionados pelas reflexões de Michel Maffesoli caminhamos à procura de um tempo presente. Esse tempo que se apresenta como intenso elã vital, como religação do ser com o mundo. Uma das possibilidades de vivermos o presente de forma plena e profunda se dá na entrega ao gozo, ao delírio de nos experimentarmos como sujeitos jogados no mundo, onde estabelecemos laços, construímos relações conosco, com o outro, com nossa natureza humana. 


\section{OF HW ollubará

ISSN: 1984-6444 | http://dx.doi.org/10.5902/1984644444577

Essa religação é uma das características fundamentais do tempo aqui e agora, que Maffesoli (2006) chamou de tempo das tribos. Como forma de criticar e combater o individualismo crescente, a partir da Modernidade, e encontrar nos contextos culturais atuais sua potência, Michel Maffesoli nos aparece como um turbilhonador, corajoso pensador nômade que busca, a partir de suas escritas, refletir sobre a sociedade através de outras e novas metáforas e, não mais, pelos conceitos de forma restrita e universal. Experimenta em sua escrita, novas palavras e termos que não se estruturam em torno da verdade absoluta e nem aspiram à totalidade dos fatos de forma tão rigorosa e paradigmática como querem alguns acadêmicos e seu cientificismo.

Como pensador nômade, não fixa morada nos conceitos, em fórmulas generalizantes, em pensamentos únicos, pelo contrário, aventura-se em um universo epistemológico escorregadio, permissível, dinâmico, poroso, tal qual a própria cultura e seus contextos se apresentam. $\mathrm{O}$ aspecto nômade de seus escritos é o que me chama a andar de mãos dadas com suas reflexões, sua ousada forma de inventar lugares e formas de analisar a cultura com a força de uma escrita pessoal, com o prazer pelo saber sem que se demore somente nas palavras e na sua duração. A força de sua escrita e seu aspecto efêmero se alia ao desejo de experimentar, na própria escrita, a possibilidade de construir redes que surgem das relações que estabelecemos no seio da cultura, onde vivemos, convivemos com o(s) outro(s) compartilhando afetos, vibrações e energias que reverberam e revigoram esse tempo do aqui e agora que se traduz em um estar-junto coletivo.

Por isso "O Tempo das Tribos6". Um retorno a alguns valores arcaicos fundadores da cultura como a fraternidade, o cooperativismo, o compartilhamento do presente onde se vive e se divide com outros. É dessa condição outra, que enfrenta as prerrogativas do Progresso e da evolução da história numa perspectiva linear, que o tribalismo presente nas discussões de Maffesoli trata de um tempo em que a busca coletiva, o prazer de estar-junto, a intensidade do momento são mais importantes do que se atingir um estado, ou um resultado, como quer a ideia do Progresso e do 


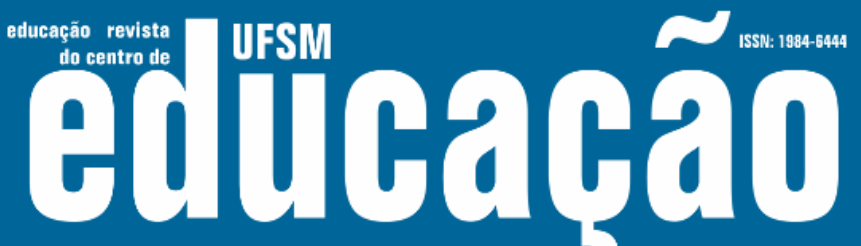

ISSN: 1984-6444 | http://dx.doi.org/10.5902/1984644444577

característica e específica que nos ajuda a alargar as discussões e compreender o espaço da Instituição Pública como um lugar potente para a instauração dessas possibilidades.

O espaço público se torna, aqui, um território de construção e criação artística composto pelas multiplicidades e experiências celebrativas da dança a partir da compreensão da importância do estar-junto na arquitetura dessa comunhão. De acordo com Maffesoli "(...) a multiplicidade do eu e a ambiência comunitária que ela induz servirá de pano de fundo à nossa reflexão. Propus chamá-la de "paradigma estético" no sentindo de vivenciar ou de sentir em comum" (2006, p. 37).

É sobre este outro paradigma, ancorado nas formas de vida que se afirmam e se apresentam pela coletividade que buscamos criar lugares a partir da escrita acadêmica para essas experiências artísticas como forma de se apropriar da cultura e seus elementos de maneira curiosa, inventiva e reflexiva.

O estar-junto como possibilidade de construção de uma teia, de uma rede coletiva nos incita a pensar sobre as intensidades, os afetos e os modos de vida que se constituem a partir do compartilhamento de saberes e experiências ex-postas nos instantes de experimentação e criação possibilitados pelos Ateliês. Reflete o desejo coletivo da busca por encontros, por descobertas de si no outro, nas convivências, criações e experimentações artísticas.

Esse modo de operar com a realidade e, portanto, com o conhecimento não se contenta apenas com a reprodução de saberes, aposta na experiência e trocas coletivas como criação e transformação da própria realidade. Trata-se de um movimento de criação que parte do já conhecido, já experimentado para pensar a condição processual e de constituição dos próprios caminhos como modo de criar outras possibilidades de compreensão e construção do conhecimento em dança. É a partir da potência do estar-junto que podemos ensinar e tecer vidas e artes para performarmos pedagogicamente. 


\title{
N-Tism

ISSN: 1984-6444 | http://dx.doi.org/10.5902/1984644444577

\section{Por uma Pedagogia Performativa: ensinar é tecer}

É bem verdade que trazer o desafio de pensar e edificar uma pedagogia performativa a partir dessas experiências significa trazer as aprendizagens e os ensinamentos que acontecem no processo. Para isso, pensar a performance como experiência é fundamental para afinar, atenuar e provocar nossos sentidos. Sem dúvidas foi Elyse Pineau que apontou cruzamentos entre a Pedagogia e a Performance e radicalizou esse modo de pensar:

\begin{abstract}
Eu quero chamar a atenção para como a performance afina e atenua nossos sentidos cinéticos e sinestésicos em relação às nossas fisicalidades habituais e às dos outros. (...) uma vez que a performance é sempre incompleta, contingente, permeável e reativa aos momentos vividos, uma vez que se desdobra na companhia dos outros, ela nos permite atravessar e pôr abaixo ilusões acerca da aprendizagem como algo isolado, linear, cumulativo e disponível à avaliação empírica (PINEAU, 2010, p.104).
\end{abstract}

A aproximação entre os campos da Pedagogia e da Performance tem apontado interessantes caminhos para professores-artistas-pesquisadores como uma forma de estabelecer pontes concretas por meio do questionamento e ações críticas para a construção de possibilidades coletivas em sedimentar lugares e espaços de ensinoaprendizagem-criação em arte como estratégias contraculturais aliadas às perspectivas de uma educação libertadora7.

Todo esse movimento constituído em torno da experiência como lócus da investigação, da criação e do protagonismo juvenil tem se dado, dentro do contexto dos Ateliês de criação em Dança, a partir de uma perspectiva que se aproxima dos Estudos da Performance ou, mais especificamente, do campo da Pedagogia Performativa alinhada a pensadores como Richard Schechner (2010), Elyse Lamm Pineau (2010), Gilberto Icle e Mônica Torres Bonatto (2017).

Desde que nos aproximamos dos Estudos da Performance toda a trajetória docente e, portanto, o exercício diário dos fazeres pedagógicos têm se tornando, também, fazeres performativos. Talvez já o fossem desde o início da carreira docente, porém, têm sido pensados sob tais perspectivas como lugar de pesquisa, investigação 


\section{Tusm outlataat

ISSN: 1984-6444 | http://dx.doi.org/10.5902/1984644444577

e intervenção ao serem concretizados e acompanhados de um mergulho mais aprofundado em tais leituras.

Descobrimos, desde então, que as trocas, as narrativas e as corporalidades com as quais lidamos vão constituindo uma rede de relações e tecendo fios numa grande teia que tem sido compartilhada e continuamente metamorfoseada nos espaços da sala de aula, nos inúmeros momentos de pesquisa e investigação durante os laboratórios de criação nos Ateliês de criação em dança.

Os percursos dessa empreitada vão dos Estudos da Performance, que permitem ampliar o próprio conceito de performance e compreender que várias ações, acontecimentos e construções humanas podem ser lidas, estudadas e refletidas como tal, às poéticas educacionais às quais estamos completamente envolvidos em um constante processo de construção coletiva em que cada encontro em sala de aula torna-se um acontecimento singular, uma tessitura de várias redes de relações que vão sendo fiadas, fabricadas, inventadas e reinventadas a partir das experiências, da performatividade dos sujeitos que coletivamente adentram esse espaço de criação e protagonismo. Ensinar e aprender como performance.

A poética da performance traz para o espaço da sala de aula as dimensões criativas, coletivas e construídas das práticas artísticas desenvolvidas nos Ateliês de criação em dança. Esse tipo de investida artística e pedagógica está engajada em um processo colaborativo continuamente criando e recriando visões de mundo em que todos os sujeitos envolvidos se encontram em posição contingencial e em constante relação de trocas.

Com efeito, a performance reenquadra todo o empreendimento educacional como um conjunto mutável e contínuo de narradores, histórias e performances, mais do que a simples e linear acumulação de competências disciplinares específicas e isoladas (PINEAU, 2010, p.97).

Desenhamos, aqui, novas possibilidades frutos das experiências adquiridas ao longo das trajetórias docentes-discentes de radicalizar e reinventar o processo de ensino-criação, em especial pela flexibilização de papéis e instauração de uma ambiência coletiva que constitui, assim, como um paradigma ético, estético e político 


\title{
Tusm Aillathá

ISSN: 1984-6444 | http://dx.doi.org/10.5902/1984644444577

do que seja ensinar, aprender, criar e produzir conhecimentos no contexto da arte e da dança.

Coletivamente criamos um corpo de trabalhos criativos que vai permitindo que cada sujeito construa e teça uma parte das grandes redes que vão se formando através dos processos que se instauram a cada encontro, a cada aula, a cada laboratório de pesquisa e criação. Essas redes são demarcadas pelas multiplicidades, pelas pluralidades de experiências com que esses sujeitos participam, se acoplam e são acoplados na tessitura de um grande conjunto de saberes, práticas, poéticas e ações que vão delineando as nuances da grande teia.

\begin{abstract}
Existem múltiplos textos, alguns são escritos; outros dançados; outros, são apenas gestos; outros, lugares; alguns textos são processos de crescimento de florescimento e decadência. Texto é uma palavra relacionada com outra, têxtil, ou fiar, fabricar tecidos de diferentes fios. Esse é o significado de texto que eu trago comigo. Múltiplos fios são tramados e destramados em diferentes tecidos de ação e significado. Ensinar é um texto- tecer (SCHECHNER, ICLE \& PEREIRA, 2010, p.30).
\end{abstract}

Assim, de acordo com os autores supracitados, uma Pedagogia Performativa se abre aos múltiplos textos e tecidos fiados nos processos de construção coletiva de ações e significados. Privilegiam as múltiplas histórias, múltiplos narradores no processo em que as narrativas da experiência humana são modeladas e compartilhadas por todos os participantes em um coletivo de performance.

A experiência da sala de aula provoca diferentes possibilidades para 0 florescimento e a fabricação das tramas, dos modos de vida que aí se instauram pelo corpo, o movimento e suas performatividades. Assim como os sujeitos da experiência, na perspectiva de Jorge Larrosa, já apontada neste estudo, a Pedagogia Performativa afirma-se nos entrelugares, nas fissuras, nas bordas dos contextos de ensino e aprendizagem para (re)inventar novas possibilidades de ação e construção de sentidos e significados através da dissolução das hierarquias e, consequentemente, das dicotomias entre professor e aluno, saber e experiência, técnicas e estéticas, dentre outras, que, por vezes, imperam nas salas de aula dos processos de formação na área de Arte. 


\section{FFM

ISSN: 1984-6444 | http://dx.doi.org/10.5902/1984644444577

Tais processos se inserem nas brechas, nas frestas e possíveis rupturas em relação aos processos educacionais que limitam e contornam os diversos contextos das Instituições de Ensino. Não ignoramos, por sua vez, que se tratam de proposições com certo tom utópico em vista das realidades com as quais lidamos nessas Instituições. Entretanto, o caráter aberto, liminar e processual dessas experiências nos permite vislumbrar outras formas de ser e estar nesses espaços.

\section{Considerações finais}

A proposta deste artigo foi pensar e problematizar as experiências docentediscentes nas disciplinas chamadas Ateliês de criação em dança I e I/ no curso de Licenciatura em Dança do Instituto Federal de Goiás (IFG) - Campus Aparecida de Goiânia através de reflexões metodológicas embasadas pela revisão de literatura. Tais disciplinas são ofertadas semestralmente, desde o primeiro período até o último do curso. De forma geral, essas disciplinas pretendem ser uma espécie de eixo estruturante em cada um dos semestres, pois lidam diretamente com os fazeres da dança em suas distintas fisionomias, formatações e inserções artísticas e sociais.

Trazer as experiências de vida e seus saberes, instaurando uma ambiência onde o estar-junto, a coletividade e o compartilhamento são as estruturas construídas para pensar novas relações de Juventude na trajetória artística e formativa desses sujeitos, tem sido a aposta empreendida nos Ateliês de criação em dança. Tais processos têm buscado a flexibilização de papéis; a ação protagonista docentediscente e a construção de novos modos de pensar e agir no seio da Instituição Pública. Assim, as experiências docente-discentes são pautadas na relação intrínseca entre o ensinar e aprender, considerados como performance.

A partir dos quatro princípios apresentados, retomados aqui de modo sucinto como sendo: 1) acordar o corpo; 2) investigações e pesquisas de movimento; 3) a experiência cênica e 4) contato com artistas convidados, os Ateliês I e I/ partem da proposta de ensino-aprendizagem-criação baseada na ideia de uma Pedagogia Performativa em Dança. Esse modo de compreensão em se construir conhecimentos de modo performativo se caracteriza pelas relações que se estabelecem entre os 


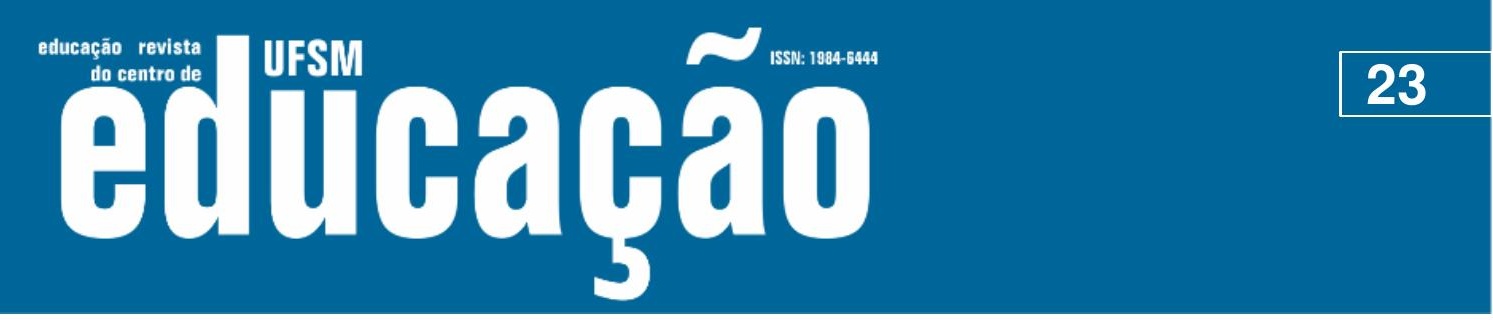

ISSN: 1984-6444 | http://dx.doi.org/10.5902/1984644444577

corpos no cotidiano da Instituição; pela maneira como esses sujeitos agem nos diferentes espaços sociais e, sobretudo, sobre a forma como a dança vem transformando seus olhares e práticas artísticas. Trata-se, portanto, da imersão em cotidianos que dançam continuamente e se reinventam a partir de processos de ensino e aprendizagem do/no corpo e constroem múltiplos sentidos e significados para as experiências docente-discentes.

Uma Pedagogia Performativa em dança tem como lócus a experiência como lugar do acontecimento, da construção de outras possibilidades para se relacionar com o próprio corpo, o movimento, os outros ao nosso redor e, particularmente, com os conhecimentos específicos da Dança. Esses processos pedagógicos e performativos compreendem a Dança como área de conhecimento que tem, na experimentação e na construção coletiva, possibilidades de criação de modos de saber e fazer particulares. Dança afetada. Dança vivida. Dança dançada.

\section{Referências}

FREIRE, Paulo. Educação como prática da liberdade. 25. ed. São Paulo: Paz e Terra, 2001. $158 \mathrm{p}$.

FREITAS, M.V. (Org.) Juventude e adolescência no Brasil: referências conceituais. São Paulo: Ação Educativa, 2005.

GUIMARÃES et al. Projeto Pedagógico do Curso (PPC) da Licenciatura em dança do IFG. Aparecida de Goiânia, 2018.

ICLE, Gilberto; BONATTO, Mônica Torres. Por uma pedagogia performativa: A escola como entrelugar para professores-performers e estudantes-performers. Cad. Cedes, Campinas, v. 37, n. 101, p. 7-28, jan.-abr., 2017

LARROSA, Jorge. Tremores: escritos sobre experiência. Trad. Cristina Antunes e João Wanderlei Geraldi. Belo Horizonte: Autêntica, 2015.

LARROSA, Jorge. Notas sobre a experiência e o saber da experiência. Revista Brasileira de Educação. Rio de Janeiro: Jan/Fev/Mar/Abr, no19, 2002, p.20-28.

MAFFESOLI, Michel. Homo eroticus: comunhões emocionais. Rio de Janeiro:Forense, 2014. 


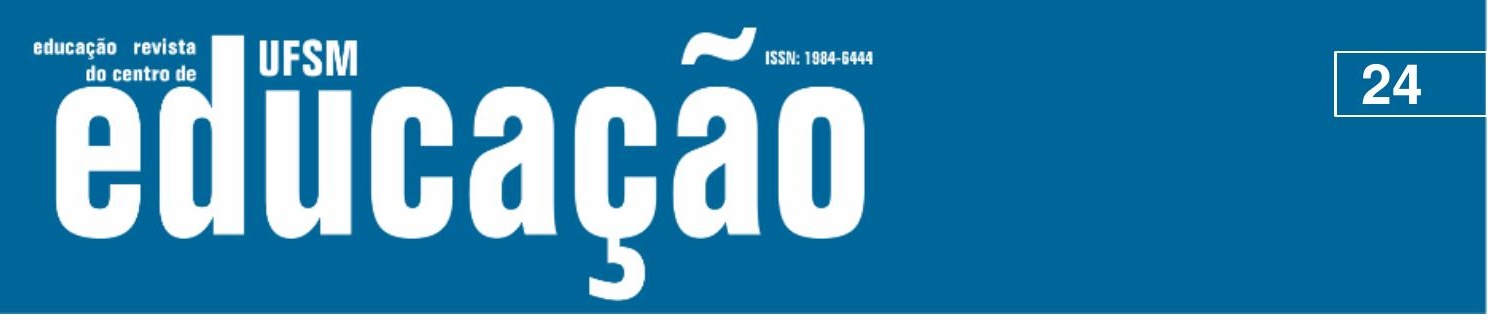

ISSN: 1984-6444 | http://dx.doi.org/10.5902/1984644444577

MAFFESOLI, Michel. O tempo das tribos: o declínio do individualismo nas sociedades pós-modernas. 4ª ed. Rio de Janeiro: Forense Universitária, 2006.

MARQUES, Isabel. Linguagem da Dança: arte e ensino. São Paulo: Digitexto, 2010.

MOLINA, Alexandre José. Dança, formação artística e o conceito de experiência. In: $V$ Congresso Nacional de Pesquisadores em Dança, ANDA, 2018, Manaus. Anais do V Congresso Nacional de Pesquisadores em Dança. Manaus: 2018, p. 2-20.

PALUDO, Luciana. O lugar da coreografia nos cursos de graduação em Dança do Rio Grande do Sul. 2015 Tese (Doutorado em Educação) - Programa de PósGraduação em Educação, Faculdade de Educação, Universidade Federal do Rio Grande do Sul, Porto Alegre, 2015.

PETRONILIO, Paulo. "LUGAR DE FALA": O GRAU DA PERFORMANCE E OUTRAS HETEROTOPIAS. Guará, Goiânia, v. 6, p. 39-59, jan./dez. 2016.

PINEAU, Elyse Lamm. Nos Cruzamentos Entre a Performance e a Pedagogia: uma revisão prospectiva. Rio Grande do Sul: Educação e Realidade, 2010.

PORTELA et al. Os saberes da experiência e a construção da poética docente para o ensino de arte. Comunicações. Piracicaba: jan.-abr, nô1, 2016, p. 225-238.

RIBEIRO, Luciana Gomes. A base nacional comum curricular foi aprovada. E agora? Como fica o ensino das artes? Boletim da FAEB. Goiânia: Maio, no1, 2018, p.5-13.

SCHECHNER, R; Icle, G; Pereira, M. O que pode a Performance na Educação? Uma entrevista com Richard Schechner. Rio Grande do Sul: Educação e Realidade, 2010.

VIANNA, Klauss. A dança. 3.ed. São Paulo: Summus, 2005.

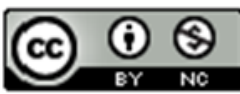

This work is licensed under a Creative Commons Attribution-NonCommercial 4.0 International (CC BY-NC 4.0)

\section{Notas}

1 Atravessado pelos estudos de Jorge Larrosa, trago para este relato o conceito de sujeitos da
experiência para pensar os discentes do curso como sujeitos que são atravessados, colocados em
constante ex-posição com os saberes advindos dos acervos de dança. Assim, Larrosa (2015) afirma
que 'o sujeito da experiência seria algo como um território de passagem, algo como uma superfície
sensível que aquilo que acontece afeta de algum modo, produz alguns afetos, inscreve algumas
marcas, deixa alguns vestígios, alguns efeitos (...) o sujeito da experiência é um ponto de chegada, um
lugar a que chegam as coisas, como um lugar que recebe o que chega e que, ao receber, lhe dá lugar 


\section{N

ISSN: 1984-6444 | http://dx.doi.org/10.5902/1984644444577

(...) o sujeito da experiência é sobretudo um espaço onde têm lugar os acontecimentos' (LARROSA, 2015, p.24).

2 Termo utilizado por Larrosa (2015) para destacar uma maneira de ex-por os conhecimentos, as experiências de maneira não passiva. Um modo de ex-posição às experiências com todos os seus riscos e vulnerabilidades. Uma forma de estarmos abertos, sensíveis às coisas, aos acontecimentos da própria experiência.

${ }^{3}$ Isabel Marques desenvolveu uma proposta metodológica chamada Dança no Contexto (USP/1996) relacionando-a aos estudos da linguagem e às propostas de Rudolf Laban.

${ }^{4}$ Todas as imagens são do acervo pessoal construído nas disciplinas Ateliê de criação em dança I e II já divulgadas em redes sociais e plataformas de imagens do curso de Licenciatura em Dança com permissões dos alunos.

${ }^{5}$ Dança à Mostra é um evento anual do curso de Licenciatura em Dança do IFG- Campus Aparecida de Goiânia que oportuniza docentes e discentes compartilharem trabalhos artísticos produzidos nas disciplinas do curso, bem como em projetos de ensino, pesquisa e extensão.

${ }^{6}$ Referência à obra de Michel Maffesoli, "O Tempo das Tribos", onde o autor defende suas posições em torno dos aspectos "concomitantes, arcaicos e juvenis do tribalismo, que põe em relevo a dimensão comunitária e a saturação do conceito de Indivíduo" (trecho do prefácio à quarta edição da obra, escrito por Luiz Felipe Baêta Neves). Nesse livro, Maffesoli analisa e constrói debates acerca dos elementos que exprimem as novas formas sociais características da pós-modernidade.

7 Em acordo com as ideias de Paulo Freire (2001) da educação como uma prática de liberdade. Neste sentido a educação libertadora é, sobretudo, uma educação conscientizadora, na medida em que além de conhecer a realidade, busca transformá-la, ou seja, tanto educador quanto educando aprofundam seus conhecimentos em torno do objeto para poder intervir sobre ele. A Dança na perspectiva da Pedagogia Performativa pode se constituir como um espaço de intervenção do/no mundo que possibilita criar caminhos para ações transformadoras da realidade. 